\title{
Analisis Kecepatan Seismik Dengan Metode Tomografi Residual Moveout
}

\author{
Imelda Murdiman*, Elistia Liza Namigo \\ Laboratorium Fisika Bumi, Jurusan Fisika, \\ Fakultas Matematika dan Ilmu Pengetahuan Alam Universitas Andalas \\ Kampus Unand Limau Manis, Padang, 25163, Indonesia \\ *imelda.murdiman.012@gmail.com
}

\begin{abstract}
ABSTRAK
Telah dilakukan analisis kecepatan menggunakan metode tomografi pada data seismik 3D Lapangan Y lepas pantai Texas dengan software Opendtect. Model kecepatan baru dibuat dengan mengoreksi kurva residual moveout (RMO) pada gather CIG (common image point) dengan menggunakan model kecepatan awal yang diperoleh secara konvensional sebagai masukan. Iterasi dilakukan sampai diperoleh kurva RMO yang datar. Selanjutnya model kecepatan baru yang dihasilkan melalui metode tomografi digunakan sebagai acuan nilai kecepatan untuk proses stacking dan migrasi. Penampang seismik hasil migrasi dengan nilai kecepatan baru menunjukkan peningkatan yang cukup baik. Struktur geologi yang berupa patahan dan pola-pola reflektor di kedalaman terlihat lebih jelas dibandingkan dengan penampang seismik awal.
\end{abstract}

Kata Kunci : tomografi, analisis kecepatan seismik, koreksi residual moveout

\section{ABSTRACT}

Velocity analysis has been performed using tomography method on 3D seismic data of field $Y$ offshore Texas by using Opendtect software. An updated velocity model was created by correcting residual moveout (RMO) curve on CIG gathers using the initial velocity model obtained conventionally as input. Iteration is performed until RMO curves are flat. The updated velocity model produced through tomography method is then used as a reference for the velocity values in the process of stacking and migration. Seismic migration with the improved velocity model improved the resolution of seismic section. Geological structures such as faults and reflector patterns at depth are more pronounced than those in the initial seismic section.

Keywords : tomography, seismic velocity model, residual moveout correction

\section{PENDAHULUAN}

Pengolahan data seismik merupakan suatu proses untuk mengolah data rekaman seismik menjadi data dalam bentuk penampang seismik yang menggambarkan bentuk penampang geologi bawah permukaaan (Zamroni, 2011). Pengolahan data seismik bertujuan untuk menghasilkan penampang seismik dengan signal to noise ratio yang baik tanpa mengubah bentuk kenampakan refleksi, sehinga dapat dilakukan interpretasi pada struktur geologi bawah bumi yang komplek, yang menjadi target dari eksplorasi dan pemboran hidrokarbon (Monalia, 2011).

Pengolahan data seismik dapat menggambarkan hasil penampang yang baik dengan dilakukan beberapa tahapan pengolahan data seismik (Herdiyantoro, 2011). Salah satu proses pada pengolahan data seismik adalah analisis kecepatan. Analisis kecepatan (velocity analysis) merupakan proses pemilihan kecepatan gelombang seismik yang sesuai. Analisis kecepatan dilakukan dengan menduga kecepatan pada suatu titik tertentu di bawah permukaan. Analisis kecepatan dilakukan untuk mendapatkan model kecepatan yang tepat.

Analisis kecepatan dapat dilakukan dengan beberapa metode seperti semblance, kirchoff, dan tomografi residual moveout, tomografi refleksi, tomografi common reflection surface. Pada penelitian ini metode yang digunakan adalah metode tomografi residual moveout. Metode semblance dan kirchoff belum mampu menghasilkan model kecepatan yang tepat karena hasil dari metode ini belum menunjukan kemenerusan reflektor yang tajam sehingga digunakanlah metode tomografi residual moveout untuk mendapatkan model kecepatan yang tepat. Metode Analisis residual moveout adalah analisis kecepatan yang dilakukan pada model kecepatan yang belum tepat. Analisis residual moveout digunakan untuk menemukan kesalahan kecepatan dalam model kecepatan. 
Berdasarkan penelitian yang dilakukan oleh Prakoso (2009) analisis tomografi dapat memberikan model kecepatan yang lebih baik sehingga penampang seismik yang dihasilkan terlihat lebih baik.

Data yang digunakan pada penelitian ini yaitu data 3D PSTM dari area sekitar High Island Lepas Pantai Texas. Daerah ini dipilih karena terdapatnya variasi kecepatan seismik yang cukup besar akibat kompleksitas struktur geologi bawah laut sehingga cocok sekali untuk menguji keefektifan metode tomografi.

\section{METODE}

Proses pengolahan data seismik terdiri dari empat tahapan utama yaitu membuat model kecepatan awal, konversi data ke domain kedalaman, migrasi kirchoff dan tomografi. Hasil keluaran tomografi yang berupa model kecepatan baru akan digunakan pada proses migrasi sehingga diperoleh penampang seismik yang berkualitas lebih baik.

\subsection{Konversi data PSTM ke PSDM}

Data awal yang digunakan yaitu data yang berdomain waktu, data ini akan dikonversi ke dalam bentuk domain kedalaman. Pengkonversian data ini menggunakan model kecepatan, dimana model kecepatan ini didapatkan dengan melakukan analisis kecepatan dengan menggunakan metode semblance. Pada tahap ini dilakukan picking kecepatan secara vertikal pada metode semblance. Picking kecepatan ini dilakukan agar didapatkan reflektor yang datar. Hasil dari tahap ini adalah sebuah model kecepatan awal yang nantinya model kecepatan ini akan diubah dalam bentuk penampang

\subsection{Migrasi kirchoff}

Pada tahap ini input data yaitu hasil dari tahap pertama yang berupa model kecepatan, lalu dilakukan migrasi kirchoff untuk menghasilkan CIG (Common image point) yang diplot pada interval kecepatan yang sesuai dengan model kecepatan awal. Proses migrasi kirchoff ini dilakukan untuk melihat reflektor-reflektor yang tidak datar. Migrasi kirchoff atau sering disebut dengan migrasi penjumlahan kirchoff adalah metode migrasi yang didasarkan pada penjumlahan kurva difraksi (diffraction summation). Metode ini merupakan suatu pendekatan secara statistik di mana posisi suatu titik di bawah permukaan dapat saja berasal dari berbagai kemungkinan lokasi dengan tingkat probabilitas yang sama. Secara praktis migrasi kirchoff dilakukan dengan cara menjumlahkan amplitudo dari suatu titik reflektor sepanjang suatu tempat kedudukan yang merupakan kemungkinan lokasi yang sesungguhnya. Keuntungan utama dari migrasi kirchoff ini adalah penampilan kemiringan curam yang baik. Sedangkan salah satu kerugiannya adalah kenampakan yang buruk jika data seismik mempunyai signal to noise ratio yang rendah (Prakoso, 2009).

\subsection{Inversi tomografi}

Tomografi merupakan cara yang tepat dan handal untuk memperbaiki model kecepatan pada kawasan kedalaman dengan melakukan analisis residual moveout (RMO). Pada proses ini dilakukan picking kecepatan pada plot CIG dengan mengkoreksi kurva RMO menggunakan metode Horizon-Based Velocity Update. Hasil dari proses ini adalah model kecepatan yang menjadi masukan untuk koreksi kecepatan berikutnya. Proses ini dilakukan secara berulang-ulang (iterasi) di sepanjang horizon sampai mendapatkan reflektor yang datar. Hasil dari tahap ini adalah sebuah model kecepatan baru yang akan menjadi masukan untuk proses migrasi.

\subsection{Migrasi}

Migrasi dilakukan pada pengolahan data seismik dengan tujuan dapat memindahkan posisi pemantul semu (hasil rekaman) ke posisi pemantul yang sebenarnya. Migrasi data seismik sebagai bagian dari proses pengolahan data seismik berusaha menghilangkan pengaruh difraksi dan efek kemiringan reflektor. Migrasi digunakan untuk menghasilkan penampang seismik yang mendekati struktur geologi bawah permukaan. 


\section{HASIL DAN DISKUSI}

\subsection{Konversi data PSTM ke PSDM}

Untuk konversi data dari PSTM ke PSDM diperlukan model kecepatan. Model kecepatan ini diperoleh melalui analisis kecepatan dengan metode picking spektrum semblance. Picking nilai kecepatan secara vertikal (vertical velocity picking) pada semblance CMP gathers domain waktu dilakukan sampai didapatkan kurva reflektor yang datar. Hasil model kecepatan terlihat pada Gambar 1

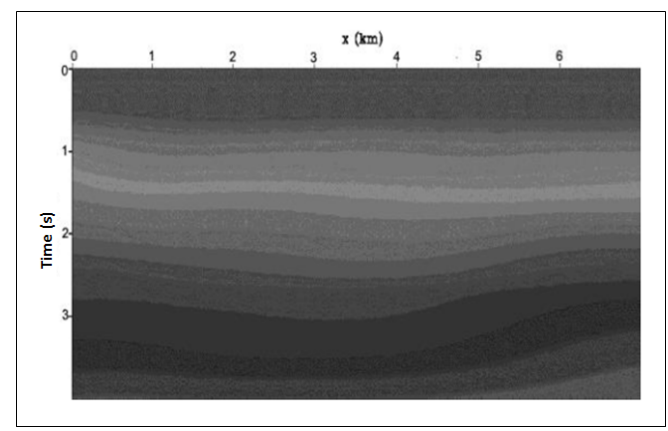

Gambar 1 Model kecepatan awal

Nilai kecepatan pada model kecepatan ini berkisar dari $1300 \mathrm{~m} / \mathrm{s}-2700 \mathrm{~m} / \mathrm{s}$. Model kecepatan yang dihasilkan terlihat seragam dan linear untuk lapisan-lapisan di berbagai variasi kedalaman, sedangkan pada keadaan sebenarnya terdapat struktur batuan yang berbeda di sepanjang kedalaman sehingga nilai kecepatan tidak seharusnya linear. Model kecepatan ini digunakan untuk mengubah data dari domain waktu (PSTM) ke domain kedalaman (PSDM) selanjutnya dilakukan konversi data PSTM ke domain kedalaman dengan menggunakan model kecepatan pada Gambar 1 sebagai masukan dan juga digunakan sebagai model kecepatan awal untuk proses tomografi.

Gambar 2 merupakan penampang seismik PSDM yang sudah dikonversi dari data PSTM. Dari penampang PSDM terlihat kemenerusan reflektornya tidak tajam dan struktur yang tidak jelas terutama di kedalaman sehingga sulit mendapatkan informasi pada penampang seismik ini. Untuk itu diperlukan update model kecepatan untuk memperoleh nilai kecepatan yang lebih tepat untuk proses migrasi.

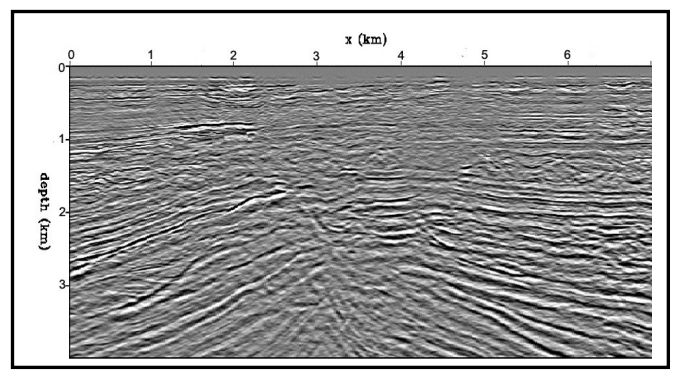

Gambar 2 Penampang seismik dalam domain kedalaman

\subsection{Migrasi kirchoff}

Setelah konversi data dari domain waktu ke domain kedalaman dilakukan migrasi kirchoff untuk menghasilkan gather Common Image Point (CIG) yang diplot sesuai dengan interval kecepatan dari model sebelumnya. Proses ini dilakukan untuk melihat bagian reflektor yang tidak datar. Hasil dari migrasi kirchoff dapat dilihat pada Gambar 3. Dari gather CIG ini terlihat terdapat lengkungan-lengkungan (misalkan kurva yang berada dalam kotak merah) yang dikenal sebagai kurva residual moveout (RMO) yang nantinya harus dikoreksi sehingga didapatkan kurva yang datar. Proses selanjutnya adalah koreksi RMO dengan inversi tomografi. Dimana CIG yang sudah diplot berdasarkan nilai kecepatan dijadikan sebagai masukan. 


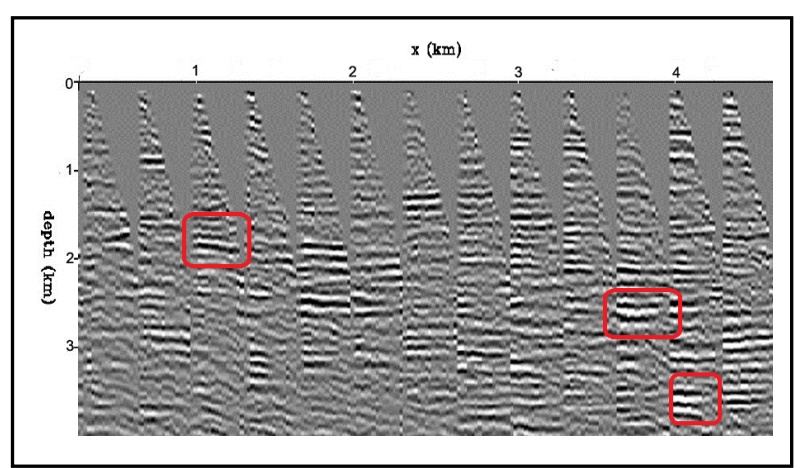

Gambar 3 Common Image Point (CIG)

\subsection{Inversi tomografi}

Pada proses ini dilakukan picking kecepatan pada plot CIG dengan mengkoreksi kurva RMO menggunakan metode Horizon-Based Velocity Picking. Koreksi RMO dilakukan dengan memilih nilai kecepatan sedemikian rupa sampai diperoleh reflektor yang yang datar (flat) pada plot CIG (Gambar 4) . Hasil dari picking kecepatan ini adalah model kecepatan baru. Proses ini dilakukan secara berulang-ulang (iterasi) untuk seluruh CIG sampai diperoleh model kecepatan yang dirasa cukup baik. Pada iterasi ke-12 didapatkan reflektor yang terlihat melengkung sudah datar. Pada Gambar 5 terlihat perbedaan reflektor sebelum dan setelah dilakukan picking velocity. Hasil koreki residual moveout dari CIG awal (Gambar 3) dapat dilihat pada Gambar 4

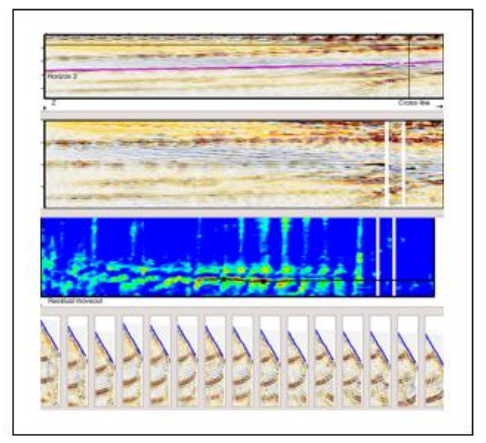

Gambar 4 Picking kecepatan dengan metode Horizon-Based

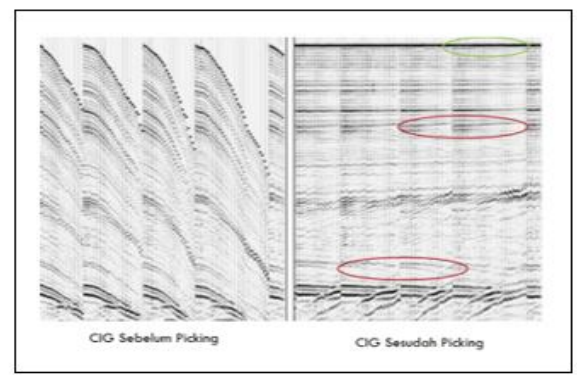

Gambar 5 CIG sebelum dan sesudah dilakukan picking velocity

Bagian yang ditandai kotak merah pada Gambar 6 menunjukan perubahan bentuk reflektor yang sudah datar untuk beberapa gather. Output dari tahap ini berupa model kecepatan. 


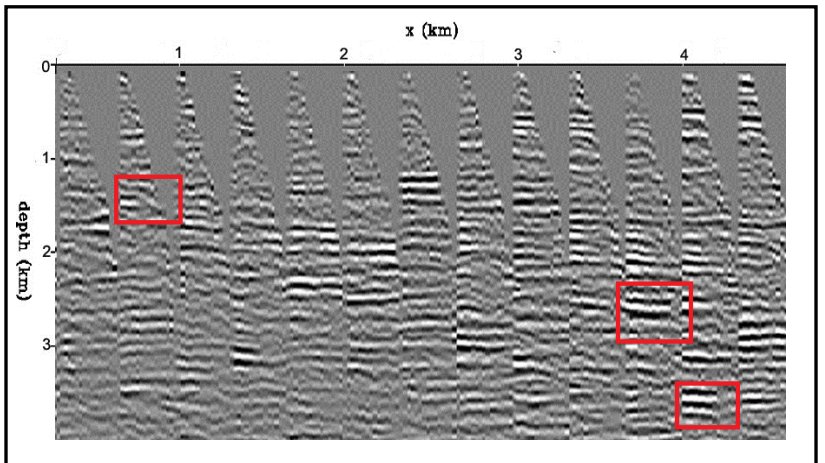

Gambar 6 CIG sesudah dilakukan picking velocity

Model kecepatan yang didapatkan dari proses picking velocity ini adalah model kecepatan baru seperti terlihat pada Gambar 7 Model ini diperoleh setelah dilakukan 12 kali iterasi. Jika dibandingkan dengan model kecepatan awal pada Gambar 1, model kecepatan ini terlihat lebih baik (lebih detil). Variasi nilai kecepatan pada model ini berkisar dari $870 \mathrm{~m} / \mathrm{s}$ sampai $2820 \mathrm{~m} / \mathrm{s}$.

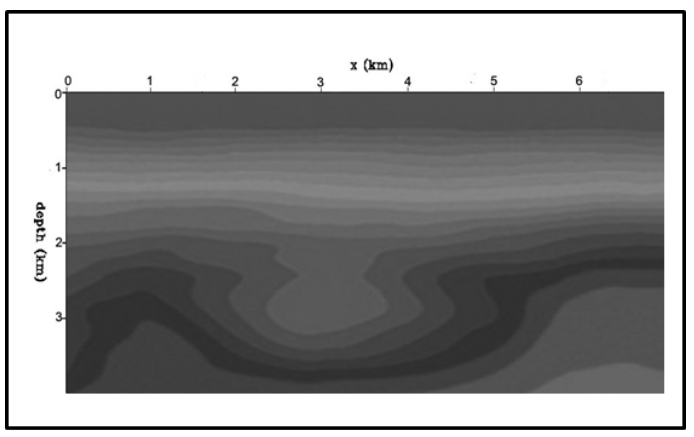

Gambar 7 Model kecepatan yang telah diperbarui

Model kecepatan yang baru ini akan digunakan untuk tahap migrasi, hasil migrasi dapat memberikan gambaran langsung dari kualitas model kecepatan yang digunakan. Gambar 8 merupakan penampang seismik hasil proses migrasi dengan menggunakan model kecepatan pada Gambar 7. Dari gambar terlihat meningkatnya kualitas penampang seismik hasil migrasi. Hal ini ditandai dengan semakin semakin tajam dan jelasnya reflektor terutama di kedalaman. Struktur geologi yang ada pada penampang yang berupa patahan (pada bagian yang dilingkari garis merah) juga terlihat semakin jelas sedangkan pada penampang awal (Gambar 2) tidak jelas adanya patahan.

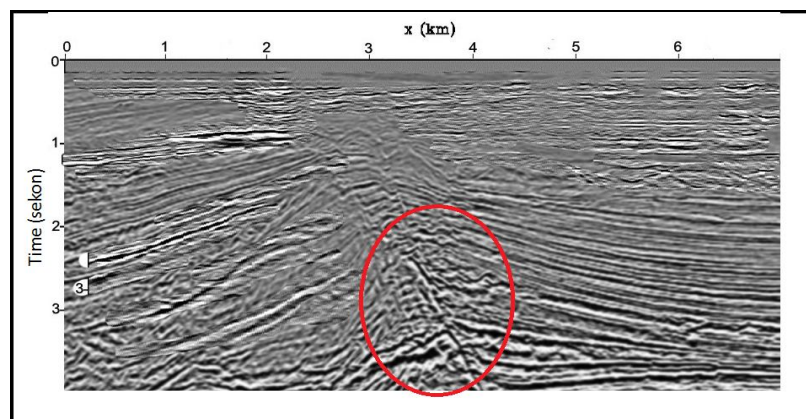

Gambar 8 Penampang seismik dengan menggunakan model kecepatan dari metode inversi tomografi

\section{KESIMPULAN}

Model kecepatan yang diperoleh dari metode analisis kecepatan konvensional tidak dapat digunakan untuk memperoleh gambaran geologi bawah permukaan. Model kecepatan ini 
harus di-update sebelum dilakukan proses migrasi pada domain kedalaman. Migrasi dengan menggunakan model kecepatan yang diperoleh dari metode tomografi menghasilkan gambar penampang seismik dengan kualitas yang lebih baik.

\section{DAFTAR PUSTAKA}

Herdiyantoro, T.P., Analisis Penampak seismik Pre Stack Time Migration dan Post Stack Time Migration Berdasarkan metode migrasi kirchoff (Jurnal Institut Teknologi Sepuluh November, Surabaya, 2011)

Monalia, P.D, "Analisis Model Kecepatan Berdasarkan Tomografi Refleksi Tempuh (Travel Time Tomografi Reflection)", Tesis S2, UI, 2011

Prakorso, P, "Migrasi Data Seismik 3D Menggunakan Metode Kirchoff Pre-Stack Depth Migration (KIRCHHOFF PSDM) Pada Lapangan Nirmala Cekungan Jawa Barat Bagian Utara", Tesis S2, UI, 2009

Zamroni, K., Analisis Kecepatan Gelombang - S Dalam Reservoar Dengan Menggunakan Persamaan Gasman Studi Kasus Sumur ' $X$ ' (Jurnal Institut Teknologi Sepuluh November, Surabaya, 2011 